\title{
Terrestrial gamma radiation dose rate in Cienfuegos, Cuba
}

\author{
C.M. Alonso-Hernández ${ }^{1}$, Y. Morera-Gomez ${ }^{1,2 \star}$, R. Acosta-Melian ${ }^{3}$, M. Sánchez-Llull ${ }^{1}$, \\ H. Cartas-Águila ${ }^{1}$, M. Díaz-Asencio ${ }^{1}$ and A. Muñoz-Caravaca ${ }^{1}$ \\ 1 Centro de Estudios Ambientales de Cienfuegos. Ctra. a Castillo de Jagua, Km 1.5. Ciudad Nuclear, CP59350 Cienfuegos, Cuba. \\ 2 Departamento de Química, Universidad de Navarra. Irunlarrea No. 1, Pamplona, 31009, España. \\ 3 Unidad de Supervisión Ambiental y Nuclear. CITMA, Cienfuegos, Cuba.
}

Received 13 November 2015 - Accepted 29 July 2016

\begin{abstract}
This study assesses the level of background radiation for Cienfuegos Province, Cuba. Measurements of outdoor gamma radiation (of terrestrial and cosmic origin) in air were performed at 198 locations using a GPS navigator and a dose meter (SRP-68-01, $30 \times 25 \mathrm{~mm} \mathrm{NaI}$ detector). The average absorbed dose was found to be $73.9 \mathrm{nGy} \mathrm{h}^{-1}$ (17.2-293.9 $\mathrm{nGy} \mathrm{h}^{-1}$ ), corresponding to an annual effective dose of $74.7 \mu \mathrm{Sv}$ (21-324 $\mu \mathrm{Sv}$ ). When compared with the data available for other places, the absorbed gamma doses obtained in this study indicate a background radiation level that falls within natural limits for the Damuji, Salado and Caonao watersheds; however, the Arimao and Gavilanes watersheds present levels of the absorbed dose and annual effective dose comparable with high background radiation areas. An isodose map of the terrestrial gamma dose rate in Cienfuegos was drawn using the GIS application "Arc View". This study provides important baseline data of radiation exposure in the area.
\end{abstract}

Keywords: Gamma radiation dose / annual effective dose / watershed / radiological map / Cuba

\section{Introduction}

Natural radionuclides are widely spread in the Earth's crust and atmosphere, which generate a significant amount of the background radiation exposure of the world's population. According to the UNSCEAR (1993), the significant radiation dose received by mankind due to natural radiation sources is about $87 \%$, and the remaining dose is due to anthropogenic radiation. Natural radionuclides of terrestrial origin are retained by many environmental materials including soils. Soil derives a predominant part of the radioactivity from the decay of the radionuclides ${ }^{238} \mathrm{U},{ }^{235} \mathrm{U},{ }^{232} \mathrm{Th},{ }^{87} \mathrm{Rb}$ and ${ }^{40} \mathrm{~K}$, and from various decay products of ${ }^{238} \mathrm{U},{ }^{235} \mathrm{U}$ and ${ }^{232} \mathrm{Th}$. Natural background radioactivity and external exposure due to gamma radiation mainly depend on the geological and geographical conditions, and are randomly distributed in soil in different regions of the world (Martins et al., 2013). Estimation of the radiation dose distribution is important in assessing the health risk to a population, and to serve as the reference in documenting changes to environmental radioactivity in soil due to human activities (Karahan et al., 2000; Mohanty et al., 2004; Saueia et al., 2005).

The province of Cienfuegos is situated in the southern central region of Cuba. It is located at $22^{\circ} 38472 \mathrm{~N}$ and $80^{\circ}$ 20111 W. Cienfuegos Province spans an area of $4187 \mathrm{~km}^{2}$

\footnotetext{
^ ymore24@gmail.com
}

with a population of about 400000 (78\% living in urban areas). Agriculture, industry and tourism are the main economic activities. Only $14 \%$ of the province is covered by forest. The principal watersheds located in the province are: Damuji $\left(1135 \mathrm{~km}^{2}\right)$, Salado $\left(132.9 \mathrm{~km}^{2}\right)$, Arimao $\left(994.5 \mathrm{~km}^{2}\right)$ and Caunao $\left(590.5 \mathrm{~km}^{2}\right)$. Water and sediments from these watersheds run off into Cienfuegos Bay (Figure 1), the principal natural ecosystem in the province.

An isodose map of terrestrial gamma radiation is indispensable for various purposes. It provides basic information for the assessment of the potential effects of low-level radiation doses and serves as a base reference level for decisions and actions in dealing with radiological accidents and emergencies. Such a map is important in the process of determining the radiological status of an area. It can also be useful in geological mapping and prospecting for minerals.

In Cuba, information related to environmental terrestrial radiation is very limited. There are only a few relevant studies (Prendes-Alonso M. et al., 1998; Tomás Zerquera et al., 2001, 2007). In Cienfuegos, Alonso-Hernández et al. (2006) published the levels of natural radionuclides in marine sediments of Cienfuegos Bay, observing an anomalous distribution. The highest concentrations and inventories of ${ }^{210} \mathrm{~Pb}$ were found in the sediments from the southern lobe of the bay. This lobe receives the freshwater input of the Caunao and Arimao rivers. Additionally, high levels of ${ }^{210} \mathrm{Po}$ were reported in marine organisms of Cienfuegos Bay (Alonso-Hernández et al., 


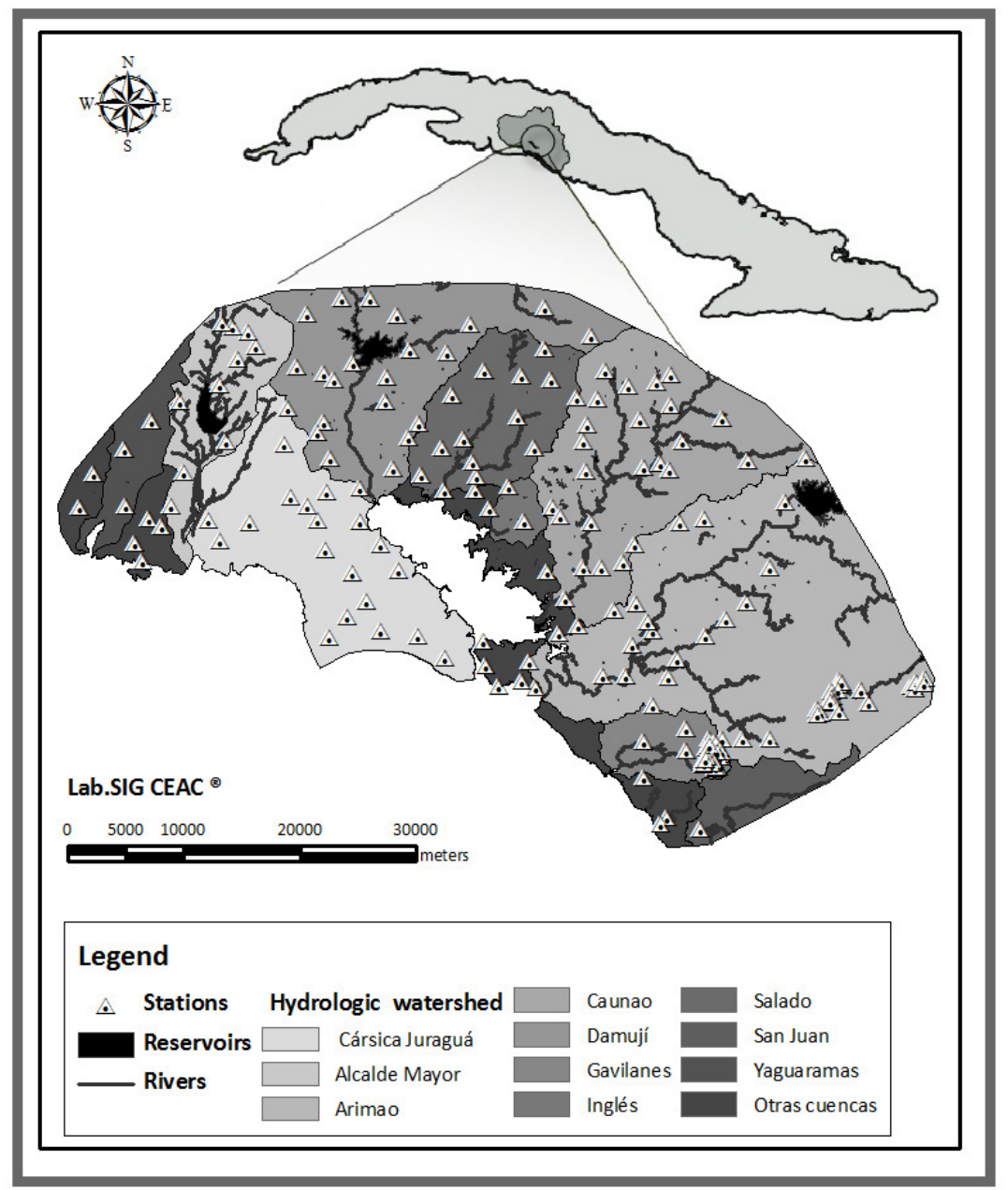

Figure 1. Map of sampling locations.

2002). Both facts suggest different input sources of natural radioactivity into Cienfuegos Bay.

To obtain the true picture as to the environmental radiation doses that are received by the population, more complete surveys must be carried out. The work described here is the first extensive survey of background radiation doses performed for Cienfuegos Province. It is aimed at establishing a database of environmental gamma radiation dose rates for reference purposes.

In consideration of the above, the objective of this work was to assess the gamma radiation dose rate from background radioactivity in Cienfuegos Province in order to delineate areas to be studied for soil content and create a digital terrestrial gamma isodose map for Cienfuegos Province.

\section{Experimental}

Detailed ambient gamma dose measurements were performed in Cienfuegos Province. The gamma absorbed dose rates in air were ascertained in 198 locations (see Figure 1) using a dose meter (SRP-68-01, 30 $\times 25 \mathrm{~mm} \mathrm{NaI}$ detector). At each site, a measurement was taken in the air for $100 \mathrm{~s}$ at $1 \mathrm{~m}$ above ground level. Six measurements were taken in each location and the average was calculated. The results, including both terrestrial and cosmic ray components of gamma radiation, were recorded in units of $\mathrm{nGy} \mathrm{h}^{-1}$.

A radiological map was constructed using GIS software (ArcGIS ArcMapTM 9.2 with their Geostatistical Analyst tool). The spatial analysis (interpolation) of raw data was performed with ordinary kriging, and adjustments to the exponential model proved to be the most adequate, revealing the lowest average standard error for all data sets.

\section{Results and discussion}

The distributions of gamma absorbed doses in air (198 readings) are given in Table 1 . The absorbed gamma doses range from 17.1 to $293 \mathrm{nGyh}^{-1}$, with an average of $73.9 \mathrm{nGy} \mathrm{h}^{-1}$. The averages and ranges of absorbed gamma doses are comparable for the Damuji, Salado and Caunao watersheds, showing levels similar to areas with normal background radiation (UNSCEAR, 2000).

However, in the Arimao and Gavilanes watersheds, the absorbed gamma doses in air are significantly higher 
Table 1. Ranges of the absorbed gamma dose and annual effective dose in watersheds of Cienfuegos Province, Cuba.

\begin{tabular}{lcccccccccc}
\hline Watershed & Sampling & \multicolumn{4}{c}{ Absorbed dose } & \multicolumn{6}{c}{ Annual effective dose } \\
\hline & point & $\boldsymbol{\mu} \mathbf{R ~ h}^{-1}$ & Min. & Max. & $\mathbf{n G y ~ h}^{-1}$ & Min. & Max. & $\boldsymbol{\mu S \mathbf { S v }}$ & Min. & Max. \\
\hline Damuji & 31 & 3.6 & 2 & 8.9 & 31.7 & 17.9 & 78.7 & 38.9 & 21.9 & 96.5 \\
Salado & 25 & 4 & 2 & 6.5 & 34.9 & 17.2 & 56.8 & 42.9 & 21 & 69.6 \\
Caunao & 28 & 4.6 & 2.1 & 9.5 & 40.2 & 18.1 & 83.3 & 49.4 & 22.2 & 102.2 \\
Arimao & 46 & 16.1 & 2.2 & 33.4 & 142.1 & 19.6 & 293.9 & 174.2 & 24.1 & 360.5 \\
Carsica Juragua & 15 & 3.1 & 2.2 & 3.6 & 27.0 & 19.1 & 31.3 & 32.9 & 23.4 & 38.2 \\
Alcalde Mayor & 10 & 3.6 & 2.1 & 6.3 & 31.3 & 18.3 & 54.8 & 38.2 & 22.3 & 66.9 \\
Gavilanes & 18 & 15.3 & 4.2 & 32.3 & 133.1 & 36.5 & 281.0 & 162.4 & 44.6 & 342.8 \\
Ingles & 12 & 3.2 & 2.2 & 3.8 & 27.8 & 19.1 & 33.1 & 34.0 & 23.4 & 40.3 \\
San Juan & 5 & 3.6 & 2.6 & 5.1 & 31.3 & 22.6 & 44.4 & 38.2 & 27.6 & 54.1 \\
Yaguarama & 8 & 3.8 & 2.6 & 4.6 & 33.1 & 22.6 & 40.0 & 40.3 & 27.6 & 48.8 \\
Total & $\mathbf{1 9 8}$ & $\mathbf{8 . 4}$ & $\mathbf{2}$ & $\mathbf{3 3 . 4}$ & $\mathbf{7 4}$ & $\mathbf{1 7 . 2}$ & $\mathbf{2 9 3 . 9}$ & $\mathbf{9 0 . 7}$ & $\mathbf{2 1}$ & $\mathbf{3 6 0 . 5}$ \\
\hline
\end{tabular}

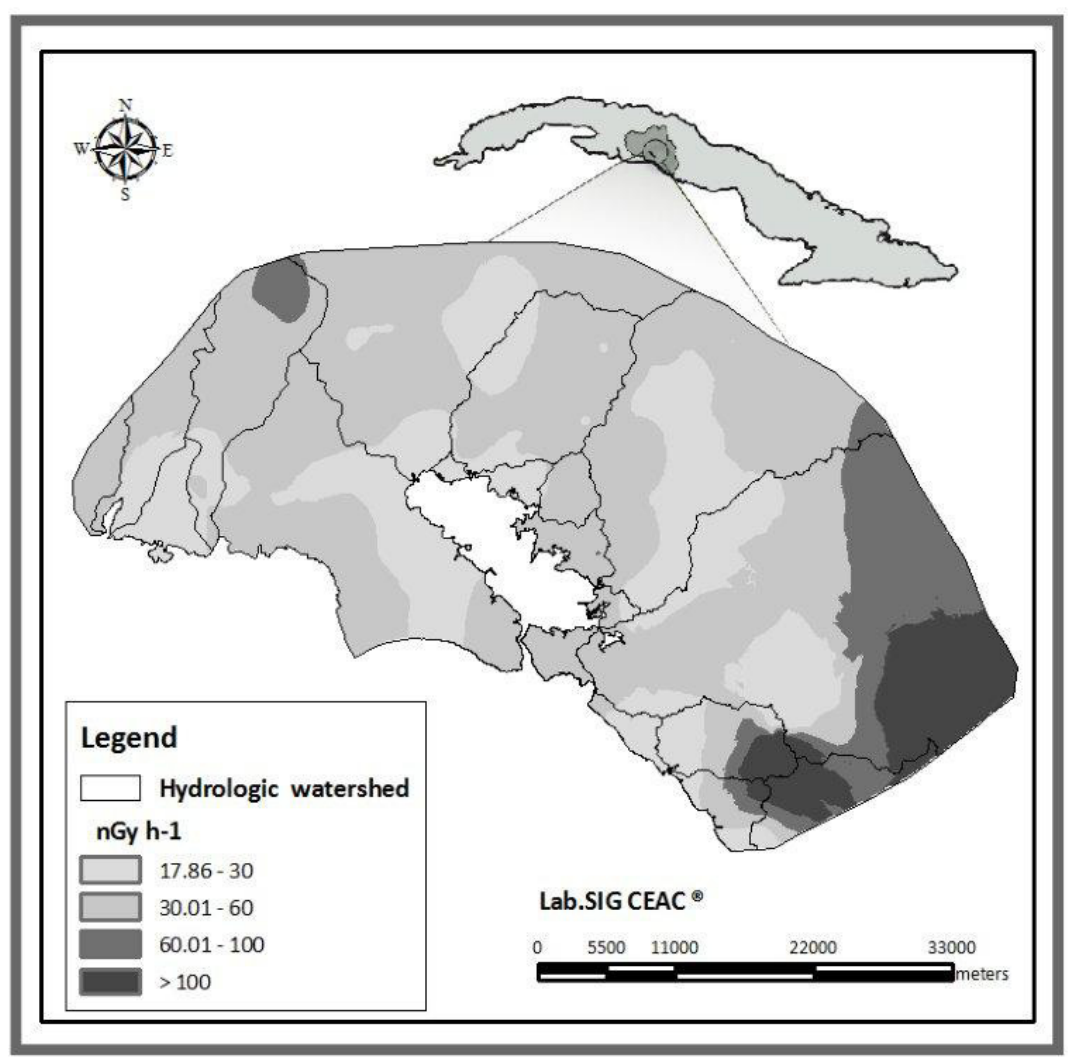

Figure 2. Absorbed dose rate map of Cienfuegos province.

$\left(\sim 300 \mathrm{nGy} \mathrm{h}^{-1}\right)$; these levels are characteristic of areas with high background radiation. This situation is attributed to the geographical or geological conditions of these regions.

In order to estimate the annual effective doses $\left(\mathrm{mSv}^{-1}\right)$, one has to take into account the conversion coefficient from the absorbed dose in air to the effective dose and the outdoor occupancy factor. In recent UNSCEAR reports (1988, 1993, 2000), the Committee used $0.7 \mathrm{~Sv} \mathrm{~Gy}^{-1}$ for the conversion coefficient from the absorbed dose in air to the effective dose received by adults, and 0.2 for the outdoor occupancy factor, implying that $80 \%$ of time is spent indoors, on average, around the world.

The calculated values of the annual effective dose due to gamma radiation therefore range from 21 to $100 \mu \mathrm{Sv}$ for the
Damuji, Salado and Caunao watersheds, with a mean value of $45.7 \mu \mathrm{Sv}$. This value is lower than the world average of $80 \mu \mathrm{Sv}$ (UNSCEAR, 1993). However, we found a different situation in the Arimao and Gavilanes watersheds, where the average of the annual effective dose due to gamma radiation is $174 \mu \mathrm{Sv}$, with a maximum level of $360 \mu \mathrm{Sv}$, four times above the world average $(80 \mu \mathrm{Sv})$.

A radiological map of gamma radiation provides basic information for assessment of the potential effects of the radiation dose and can be used as a baseline for future investigations.

The map of the outdoor gamma dose $\left(n \mathrm{~Gy} \mathrm{~h}^{-1}\right)$ for Cienfuegos Province is shown in Figure 2. The map shows that 
more than $80 \%$ of the area of Cienfuegos Province has gamma absorbed doses below $60 \mathrm{nGy} \mathrm{h}^{-1}$, characteristic of areas with normal background radiation. Levels above $200 \mathrm{nGy} \mathrm{h}^{-1}$ were obtained in the east of the Arimao and Gavilanes watersheds, representing about $24 \%$ of the territory. These higher values obtained in the Arimao and Gavilanes watersheds are probably due to the geological predominance of igneous acidic intrusive granitic rocks in the area. Granitic rocks, because of their mineralogical composition (e.g. zircon, monazite, apatite, titanite, xenotime), are likely to contain high concentrations of natural radionuclides (Orgun et al., 2005; Ramasamy et al., 2005; Kapdan et al., 2012; Papadopoulos et al., 2012; Martins et al., 2013). These results may explain the irregular distribution of ${ }^{210} \mathrm{~Pb}$ in the sediments of Cienfuegos Bay (Alonso-Hernández et al., 2006).

Future studies of these anomalies will be necessary to understand the composition of radionuclides in environmental samples (soil, water and crops), to study the contribution from the cosmic component in the area and to evaluate the effects on the health of the resident population.

\section{Conclusions}

The gamma absorbed doses in air from terrestrial and cosmic ray radiation within the territory of Cienfuegos range from 17 to $294 \mathrm{nGy} \mathrm{h}^{-1}$. The average gamma absorbed dose in air was $74 \mathrm{nGyh}^{-1}$, corresponding to an annual effective dose of about $90.3 \mu \mathrm{Sv}$. The spatial distribution of gamma absorbed doses in Cienfuegos Province showed that the Damuji, Salado and Caunao watersheds have values similar to areas with normal background radiation, while the Arimao and Gavilan watersheds present levels of the absorbed dose and annual effective dose comparable with high background radiation areas. These anomalies are probably due to the geological conditions of the area, where a granitic block is present. A radiological map of the gamma radiation of Cienfuegos Province is now available for the first time in this region, and can provide basic information for assessment of the potential effects of the radiation dose.

Acknowledgements. This research work was undertaken in the framework of the IAEA TC Project CUB/7/008 "Strengthening the National System for Analysis of the Risks and Vulnerability of Cuba's Coastal Zone Through the Application of Nuclear and Isotopic Techniques" and National Program PNUOLU /4-1/ 2 No. /2014 of the National Nuclear Agency.

\section{References}

Alonso-Hernández C.M., Díaz-Asencio M., Muñoz Caravaca A., Suarez-Morell E., Ávila-Moreno R. (2002) ${ }^{137} \mathrm{Cs}$ and ${ }^{210}$ Po dose assessment from marine food in Cienfuegos Bay (Cuba), $J$. Environ. Radioact. 61, 203-211.
Alonso-Hernández C.M., Díaz-Asencio M., Muñoz-Caravaca A., Delfanti R., Papucci C., Ferretti O., Crovato C. (2006) Recent changes in sedimentation regime in Cienfuegos Bay, Cuba, as inferred from ${ }^{210} \mathrm{~Pb}$ and ${ }^{137} \mathrm{Cs}$ vertical profiles, Continental Shelf Research 26, 153-167.

Kapdan E., Varinlioglu A., Karahan G., Taskin H., Okka M., Kiziltas S., Karahan S. (2012) Natural and anthropogenic radionuclides in the granitic region of Kapidag peninsula, Western Anatolia, Turkey, Radiat. Prot. Dosim. 150, 448-457.

Karahan G., Ozturk N., Bayulken A. (2000) Natural radioactivity in various surface waters in Istanbul, Turkey, Water Res. 34, 43674370.

Martins L.M.O., Gomes M.E.P., Neves L.J.P.F., Pereira A.J.S.C. (2013) The influence of geological factors on radon risk in groundwater and dwellings in the region of Amarante (Northern Portugal), Environ. Earth Sci. 68, 733-740.

Mohanty A.K., Sengupta D., Das S.K., Saha S.K., Van K.V. (2004) Natural radioactivity and radiation exposure in the high background area at Chhatrapur beach placer deposit of Orissa, India, J. Environ. Radioact. 75, 15-33.

Orgun Y., Altinsoy N., Gultekin A.H., Karahan J., Celebi N. (2005) Natural radioactivity levels in granitic plutons and groundwaters in Southeast part of Eskisehir, Turkey, Appl. Radiat. Isotopes 63, 267-275.

Papadopoulos A., Christofides G., Koroneos A., Stoulos S., Papastefanou C. (2012) Natural radioactivity and dose assessment of granitic rocks from the Atticocycladic Zone (Greece), Periodico di Mineralogia 81, 301-311.

Prendes-Alonso M., Alonso-Hernández C.M., Tomaz-Zerquera J., Cornejo-Díaz N., Díaz-Asencio M., Hernández Gómez I.M., Avila-Moreno R. (1998) Estudio de la carga radiacional a miembros del público en el emplazamiento de la central electronuclear de Juraguá por la operación de la instalación, Nucleus 25, 54-62.

Ramasamy V., Ponnusamy V., Meenakshisundaram V., Gajendran V. (2005) Evaluation of natural radioactivity and radiological hazards in various granites of Tamilnadu, Indian Journal of Physics and Proceedings of the Indian Association for the Cultivation of Science 79, 1293-1297.

Saueia C.H., Mazzilli B.P., Favaro D.I.T. (2005) Natural radioactivity in phosphate rock, phosphogypsum and phosphate fertilizers in Brazil, J. Radioanal. Nucl. Chem. 264, 445-448.

Tomás Zerquera J., Prendes Alonso M., Brigido-Flores O., Hernández Pérez A. (2001) Study on external exposure doses received by the Cuban population from environmental radiation sources, Radiat. Prot. Dosim. 95, 49-52.

Tomás Zerquera J., Prendes Alonso M., Díaz Rizo O. (2007) Distribution of doses received by Cuban population due to environmental sources of radioactivity, Radiat. Prot. Dosim. 123, 118-123.

UNSCEAR (1988) Ionizing radiation: sources and biological effects. United Nations, New York.

UNSCEAR (1993) Sources and effects of ionizing radiation. Annex A. Exposures from natural sources of radiation. United Nations, New York.

UNSCEAR (2000) Ionizing radiation: sources and biological effects. United Nations, New York.

Cite this article as: C.M. Alonso-Hernández, Y. Morera-Gomez, R. Acosta-Melian, M. Sánchez-Llull, H. Cartas-Águila, M.

Díaz-Asencio, A. Muñoz-Caravaca. Terrestrial gamma radiation dose rate in Cienfuegos, Cuba. Radioprotection 51(4), 245-248 (2016). 